\title{
A new genus of Lachesillidae (Psocoptera) from the Peruvian Amazonia
}

\author{
ALFONSO N. GARCÍA ALDRETE \\ Departamento de Zoología, Instituto de Biología, Universidad Nacional Autónoma de México, Apartado Postal 70-153, 04510 \\ México, D. F. MÉXICO. E-mail:anga@ibiologia.unam.mx
}

Mockford \& Sullivan (1986), proposed a higher classification of the psocopteran family Lachesillidae, in which they established the subfamilies Lachesillinae and Eolachesillinae. In the latter subfamily they created two tribes, Eolachesillini and Graphocaeciliini, and dealt with the systematics of the latter. In the Graphocaeciliini they recognised eight genera, including six new genera, and 29 species in total. Subsequently, García Aldrete (2006) erected the genus Waoraniella from the Ecuadorian Amazonia, and established for it the tribe Waoraniellini, in the Eolachesillinae; García Aldrete \& Mockford (2011 b) described a second species of that genus, from the Reserva Florestal Ducke, near Manaus, Brazil, and indicated that a third species is known to occur in the Peruvian Amazonia, near Iquitos; finally, García Aldrete \& Mockford (2011 a) described the genus Amazolachesilla, in the Graphocaeciliini, from the Brazilian state of Amazonas.

The Amazon basin continues to offer biological novelties: two male specimens of Eolachesillinae: Graphocaeciliini, taken recently in the Peruvian Amazonia, are not assignable in any of the known genera in that tribe. They thus represent a new genus, and the purpose of this paper is to describe and illustrate it, and to attempt to relate it to the other genera in the tribe.

The two specimens available for study were dissected in $80 \%$ ethyl alcohol, and their parts (head, right legs and wings, and genitalia) were mounted on slides in Canada Balsam. Color was recorded by placing the whole specimens, before dissection, under a stereo microscope, illuminated with cold white light at 80X. Parts on the slides were measured with a filar micrometer, and illustrations were made by means of a drawing tube. Abbreviations of parts measured are as follows: FW: length of right forewing, HW: length of right hindwing, F, T, t1 and t2: lengths of femur, tibia and tarsomeres 1 and 2 of right hind leg, ctt1: number of ctenidobothria on t1, Mx4: length of fourth palpomere of right maxillary palpus, f1...fn: length of flagellomeres $1 \ldots \mathrm{n}$ of right antenna, IO, D and d: minimum distance between compound eyes, antero-posterior diameter and transverse diameter, respectively, of right compound eye on dorsal view of head, PO: d/D. The location of the types is indicated in the description.

\section{Cuzcolachesilla gen. n.}

Diagnosis. With the characters of the tribe plus the following: Ocelli absent. Phallosome open anteriorly, side struts long, slender. External parameres broad, distally blunt, bearing pores, articulated anteriorly with posterior ends of side struts. Aedeagal arch stout, strongly sclerotized, distally rounded. Endophallus with four large sclerites in a membranous matrix (Fig. 3). Clunium extended posteriorly over the area of the epiproct, the extension clearly divided in two; clunium also with a long, tubular posterior projection on each side, between each paraproct and epiproct, widened distally, apparently hollow, with setae on surface (Fig. 4). Hypandrium bowl-shaped, slightly projected posteriorly, surface setose, with two mesal macrosetae, one near each side.

Type species: Cuzcolachesilla cashiriariensis $\mathbf{n} . \mathbf{s p .}$

\section{Cuzcolachesilla cashiriariensis n. $\mathbf{s p .}$}

(Figs. 1-4)

Color (in $80 \%$ ethyl alcohol). Body tawny brown. Compound eyes black. Wings hyaline, with a light orange hue. Abdomen with transverse, ochre subcuticular rings, less pigmented ventrally. 
Morphology. As in generic diagnosis, plus the following: forewing pterostigma narrow anteriorly, wide posteriorly, almost rectangular; hypandrium bowl-shaped, posterior margin obtusely convex, lateral and posterior margins strongly sclerotized; sparsely ciliated over the surface, with two setae distinctly longer than the others, one near each side. Paraprocts semicircular, with setae as illustrated, sensory fields with 15-16 trichobothria in basal rosettes; epiproct trapeziform, with field of setae on posterior third. Pretarsal claws with minute preapical denticle, pulvillus broad.

Measurements. FW: 2154, HW: 1708, F: 533, T: 927, t1: 343, t2: 102, ctt1: 17, Mx4: 121, f1: 483, f2: 347, f3: 273, f4: 226, IO: 201, D: 289, d: 194, IO/d: 1.03, PO: 0.67.

Material studied. Holotype male, 1 paratype male. PERU, Cuzco, Cashiriari (light). 4-22.viii.2005. J. Williams. Deposited in the National Insect Collection (CNIN), Instituto de Biología, Universidad Nacional Autónoma de México. México City, México.

Etymology. The specific name refers to the type locality, Cashiriari.

\section{Key to the genera of Graphocaeciliini}

(Modified from Mockford \& Sullivan, 1986)



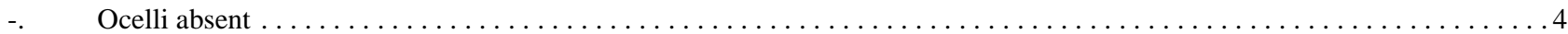

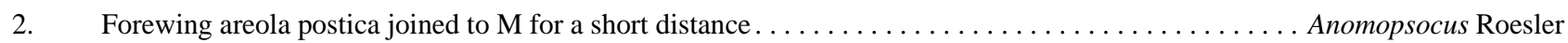

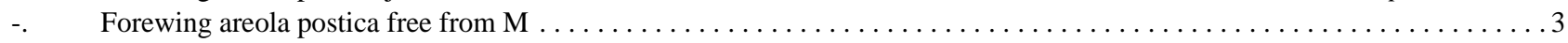

3. Aedeagus broad and truncated distally; V2+3 terminating as a slender process ........ Mesolachesilla Mockford \& Sullivan

-. Aedeagus terminating as an acuminate process; V2+3 broadly rounded distally. . . . . . . . . Graphocaecilius Enderlein

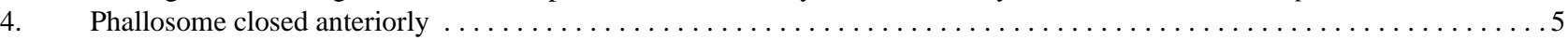

-. Phallosome open anteriorly; clunium with one tubular projection between each paraproct and epiproct, and with one broad projection, with a median posterior concavity, over the area of the epiproct............... Cuzcolachesilla gen. $\mathbf{n}$.

5. Phallosome distinctly stemmed anteriorly, or anteriorly round, slightly extended; endophallus with some minute denticles and

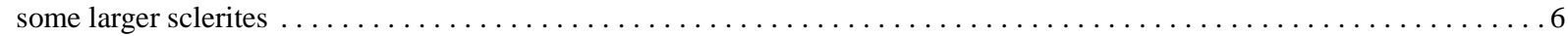
Phallosome anteriorly flat; endophallic sclerites entirely minute denticles $\ldots \ldots \ldots \ldots \ldots \ldots \ldots \ldots \ldots \ldots \ldots \ldots$

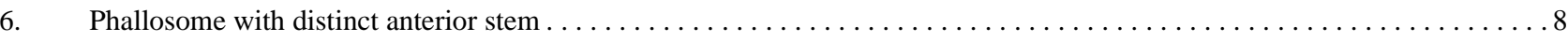

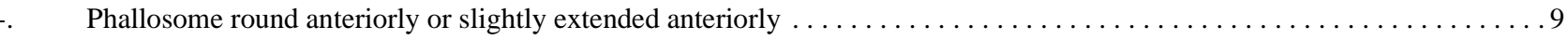

7. Aedeagus terminating in a pointed or knobbed process; arms of aedeagus ribbon-like, capable of pleat-folding; each arm joining base of phallosome on lateral side of strut to external paramere ............. Prolachesilla Mockford \& Sullivan

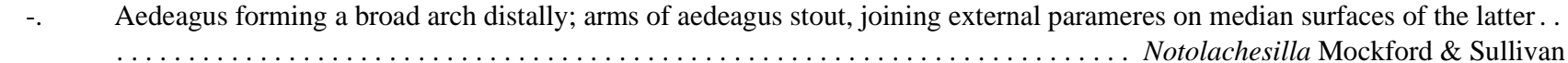

8. Aedeagus rounded, endophallus with four sclerites, two small and two large; male clunium with a large triangular projection, flanked by sclerotized rods, over the area of the epiproct, also, a sclerotized rod next each paraproct, on outer edge ........

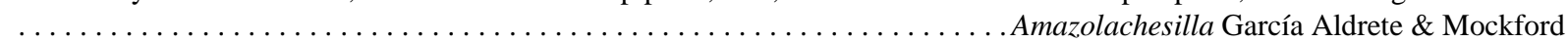
Aedeagus extended posteriorly in the middle; male clunium slightly extended over base of epiproct as a short shelf ........

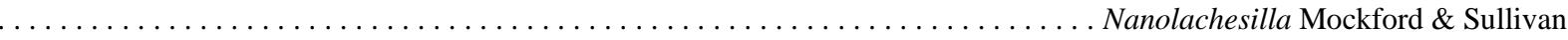

9. Aedeagus terminating in a broad knob; male clunium slightly extended over base of epiproct to form an obtusely concave projection; endophallus with two large, chelate sclerites and many minute denticles........ Antilachesilla Mockford \& Sullivan Aedeagus a heavily sclerotized piece, terminating in a broad process bifid at its tip; male clunial projections over base of paraprocts and epiproct complex; endophallus with numerous, large chelate sclerites and many minute denticles...........

. Tricholachesilla Mockford \& Sullivan

Remarks. Species in the following genera of Graphocaeciliini all lack ocelli: Antilachesilla, Prolachesilla, Nanolachesilla, Tricholachesilla, Notolachesilla (all by Mockford \& Sullivan), and Amazolachesilla García Aldrete \& Mockford. Cuzcolachesilla differs from these in having an anteriorly open phallosome. The bowl-shaped hypandrium in Cuzcolachesilla is somewhat similar to that in Tricholachesilla and in Nanolachesilla, but lacks the side projections of the latter. From the genera above, the males of the first, second, third and fifth have the clunium projected posteriorly only in the area of the epiproct, whereas the males of Tricholachesilla and Amazolachesilla have side projections over the area of the paraprocts, besides the central clunial projection, over the base of the epiproct. The side clunial projections in Tricholachesilla are formed by a central lobe, that bears on the inner side a short lobe beset with short spines; the central lobe extends to the outer side to form an acuminate projection. This clunial projection over the area of the paraprocts does not extend over the level of the central projection (see Fig. 138 in Mockford \& Sullivan, 1986). In Amazolachesilla, the clunial projections are complex, formed by a triangular extension over the base of the epiproct, flanked by a long, slender, sclerotized rod, and there is another, similar rod, next to each paraproct on its outer edge (see Fig. 3 in García Aldrete \& Mockford, 2011). Differing from the above, the clunial projections in Cuzcolachesilla are 
much simpler: the projection over the base of the epiproct is broad, with a posterior concavity in the middle, and the projections between each paraproct and epiproct are tubular, setose, wide distally and apparently hollow (see Fig. 4), extending well over the level of the central projection, distinctly different from those in Tricholachesilla and Amazolachesilla. That character, together with the anteriorly open phallosome, set this genus apart from the genera lacking ocelli in the tribe Graphocaeciliini.
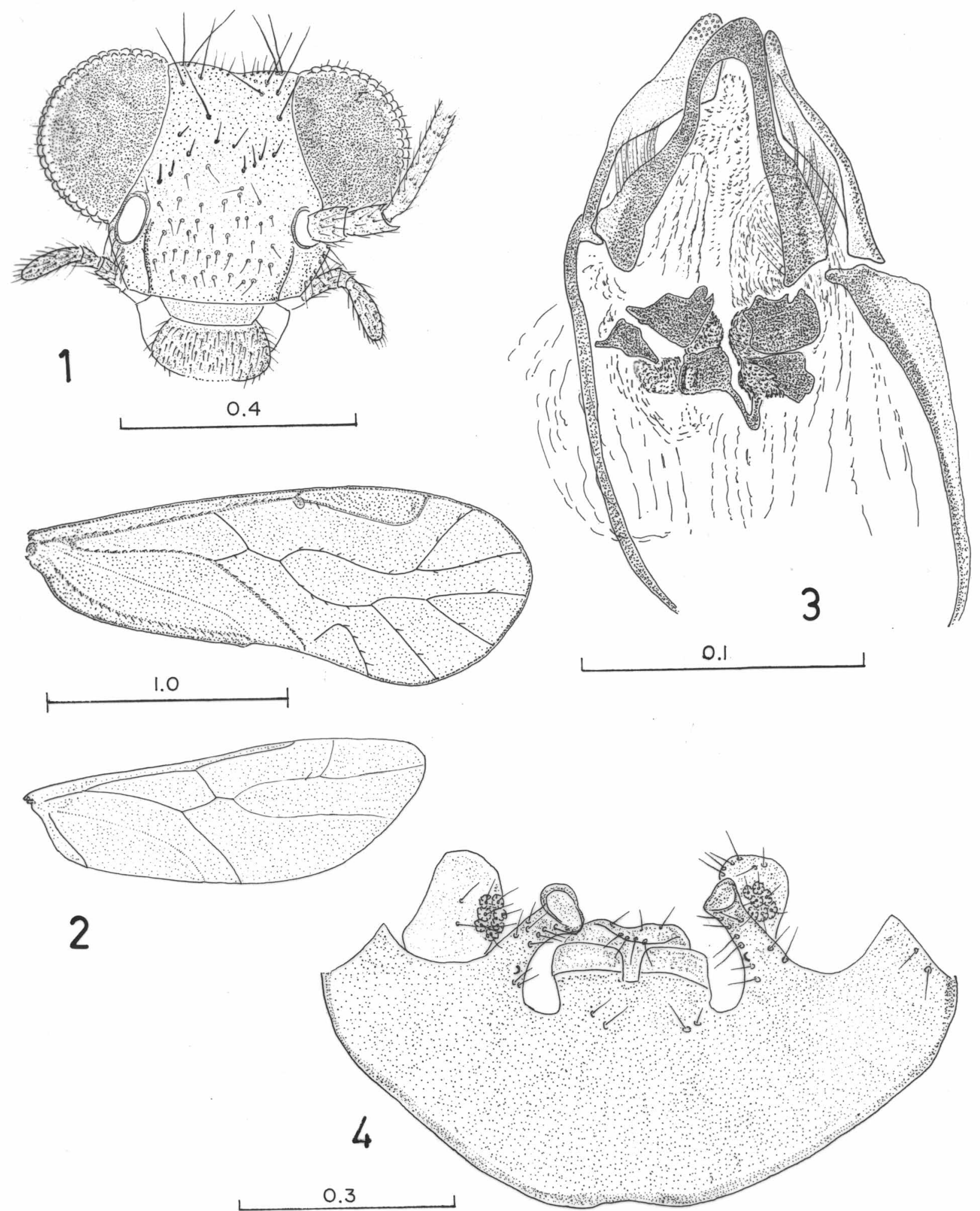

FIGURES 1-4. Cuzcolachesilla cashiriariensis sp. n. Male. 1. Front view of head. 2. Forewing and hindwing. 3. Phallosome. 4. Clunium, paraprocts and epiproct. Scales in $\mathrm{mm}$. 


\section{Acknowledgments}

I thank Dr. Diego Carpintero (Museo Argentino de Ciencias Naturales Bernardino Rivadavia, Buenos Aires, Argentina), for donating the specimens here studied. I also thank Instituto de Biología, Universidad Nacional Autónoma de México, for continuous research support.

\section{References}

García Aldrete, A.N. (2006) New genera of Psocoptera (Insecta), from Mexico, Belize and Ecuador (Psoquillidae, Ptiloneuridae, Lachesillidae). Zootaxa, 1319, 1-14.

García Aldrete, A.N. \& Mockford, E.L. (2011 a) Amazolachesilla, a new genus of Eolachesillinae (Insecta: Psocodea:’Psocoptera": Lachesillidae) from Amazonas, Brazil. Acta Amazonica, 41(4), 553-556.

García Aldrete, A.N. \& Mockford, E.L. (2011 b) A new species of Waoraniella (Psocodea: 'Psocoptera': Lachesillidae) from the Reserva Florestal Ducke, Amazonas, Brazil. Acta Zoológica Mexicana (n. s.), 27 (1), 123-127.

Mockford, E.L. \& Sullivan, D.M. (1986) Systematics of the graphocaeciliine psocids with a proposed higher classification of the family Lachesillidae (Psocoptera). Transactions of the American Entomological Society, 112 (1), 1-80. 